\title{
EVALUATION OF THE PREVALENCE OF ESBL MULTI- RESISTANT BACTERIA, CARBAPENEMASE PRODUCING ENTEROBACTERIACEAE IN URINARY TRACT INFECTIONS
}

\author{
Alina Oana Iacob (Cucian)1 ${ }^{1}$, Septimiu Tader Voidazan², Nicolae Ovidiu Pop ${ }^{3.4}$ \\ ${ }^{1}$ County Emercency Clinical Hospital Târgu-Mures, Romania \\ ${ }^{2}$ University of Medicine, Phamacy, Sciences and Technology of Târgu Mureș, Romania \\ ${ }^{3}$ University of Oradea, Faculty of Medicine and Pharmacy, Romania \\ ${ }^{4}$ County Emergency Clinical Hospital Oradea \\ Corresponding author: \\ Alina Oana lacob (Cucian) \\ cucianalinaoana@yahoo.com
}

\begin{abstract}
Microbial resistance to antibiotics represents a complex global, cross-border and intergenerational problem that requires interventions in due time, taking into consideration the enormous potential impact on human health.

The purpose of this study is to evaluate the prevalence of extended-spectrum beta-lactamase producing bacteria (ESBL), carbapenemase-producing enterobacteriaceae (CPE) multidrugresistant bacteria in urinary tract infections in the County Emergency Clinical Hospital of TârguMureş during 2017-2018.
\end{abstract}

Keywords: ESBL, CPE, multidrug resistance.

\section{Abstract}

Rezistența microbiană la antibiotice reprezintă o problemă globală, transfrontalieră și intergenerațională complexă, care necesită intervenții în timp util, luând în considerare impactul potențial enorm asupra sănătății umane.

Scopul acestui studiu este de a evalua prevalența bacteriilor multirezistente la antibiotice (bacterii producătoare de beta-lactamaze cu spectru larg, bacterii producătoare de carbapenemază), la pacienții cu infecții ale tractului urinar în Spitalul Clinic Județean de Urgență din Târgu-Mureș în perioada 2017-2018.

Cuvinte cheie: ESBL, CPE, rezistență la medicamente. 


\section{INTERNAL}

\section{Original Papers}

\section{Introduction}

Some national and international organizations (WHO, UE, CDC, ECDC, IDSA) have developed strategies that indicate caution in the use of antibiotics in humans and animals, as well as the importance of hygiene measures in health care. In 2001, the European Commission proposed a community system "Strategies against microbial resistance" consisting of four key components: surveillance, prevention, research and the development of antibiotics and vaccines, as well as international cooperation. The UE aims an international cooperation, in particular with WHO, to promote the rational use of antibiotics $^{(1)}$.

Urinary tract infections (UTIS) are the most common bacterial infections found in the clinical medicine. Escherichia coli is the most commonly isolated pathogen in these infections. The Study for Monitoring Antimicrobial Resistance Trends (SMART) is a worldwide antibiotic resistance monitoring program, being in progress and monitoring the susceptibility of Gram-negative bacilli in intra-abdominal infections, since 2002. In 2005 and 2006the final results of the study on microbial resistance to antibiotics in case of urinary tract infections in non-hospitalized patients in North America are published. Monitoring the susceptibility of Gramnegative bacilli from patients hospitalized with UTI was initiated in 2009. The study presented by Hoban DJ, Nicolle LE, Hawser S in 2011 is the first report describing in vitro the sensitivity of $E$. coli isolates to parenteral antibiotics used in the treatment schemes of patients hospitalized with $\mathrm{UTI}^{(2,3)}$.

The urinary tract infection is defined by the presence of microorganisms in the urinary tract that is usually sterile. Urinary tract infection is one of the most common pathological conditions. An appreciable number of UTIs develop asymptomatically, and in children under 2 years of age the symptoms of UTI are nonspecific. Urinary tract infections have a higher incidence in women, $50 \%$ of them suffering at least once in their life from a form of urinary tract infection. Young men are rarely affected by these infections. On the other hand, men over 50 years of age with prostate disease (hypertrophy or inflammation of the prostate, which prevents bladder emptying) are more exposed to the risk of urinary tract infections. Urinary tract infections in children are rarer, affecting about $2 \%$ of the paediatric population ${ }^{(4)}$.

There are three types of urinary tract infections, depending on the location of the infection: cystitis, urethritis and pyelonephritis. Cystitis represents the inflammation of the bladder. By far the most common form of urinary tract infection, it affects predominantly women only. In most 


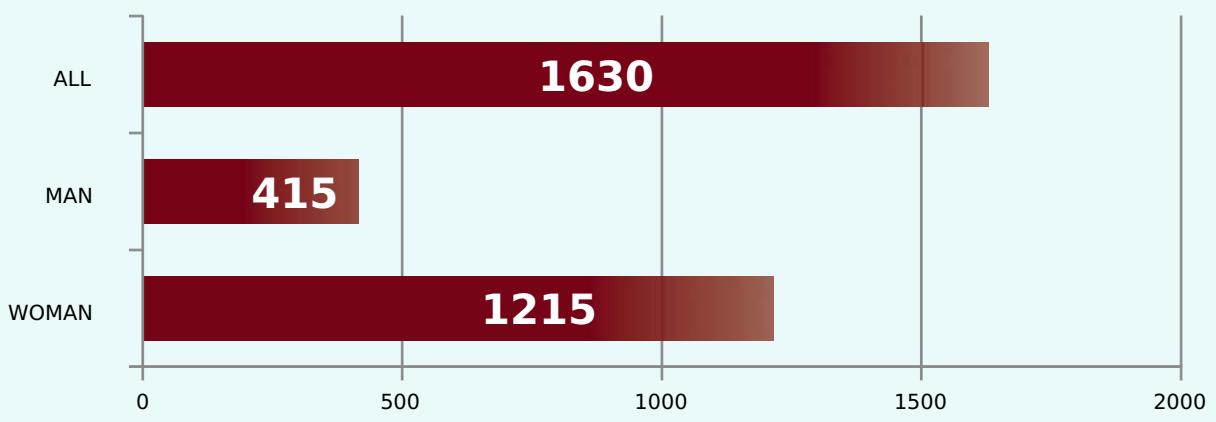

Figure 1. Distribution by gender

$$
\begin{array}{llllllllll}
\mathbf{S} & \mathbf{T} & \mathbf{A} & \mathbf{T} & \mathbf{I} & \mathbf{S} & \mathbf{T} & \mathbf{I} & \mathbf{C} & \mathbf{S}
\end{array}
$$

\begin{tabular}{ccc}
\multicolumn{3}{c}{ Age } \\
\hline $\mathrm{N}$ & Valid & 1630 \\
\hline Missing & 0 \\
\hline Mean & 54,05 \\
\hline Median & 64,00 \\
\hline Std. Deviation & 27,556 \\
\hline Minimum & 0 \\
\hline Maximum & 94
\end{tabular}

Figure 2. Distribution by age

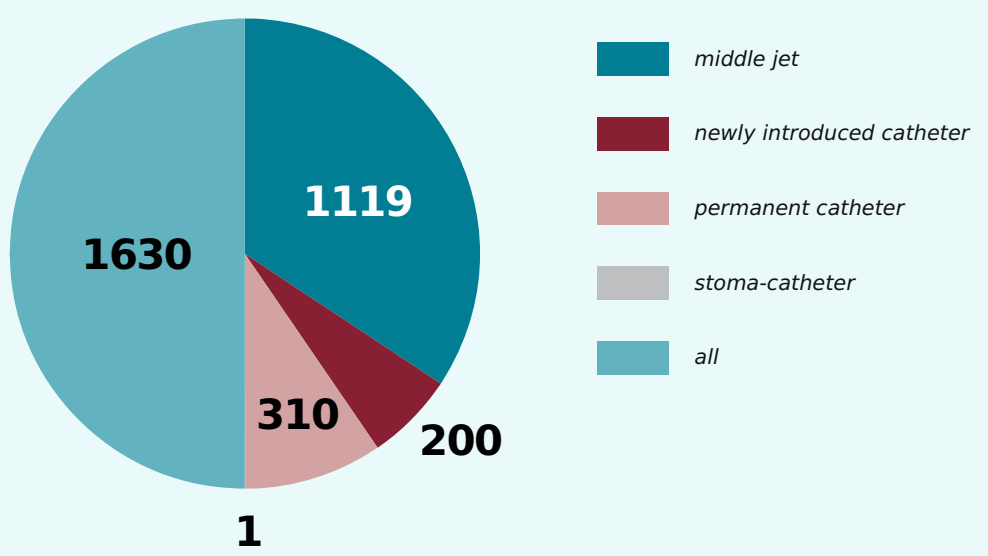

Figure 3. Distribution according to collecting method 


\section{INTERNAL}

\section{Original Papers}

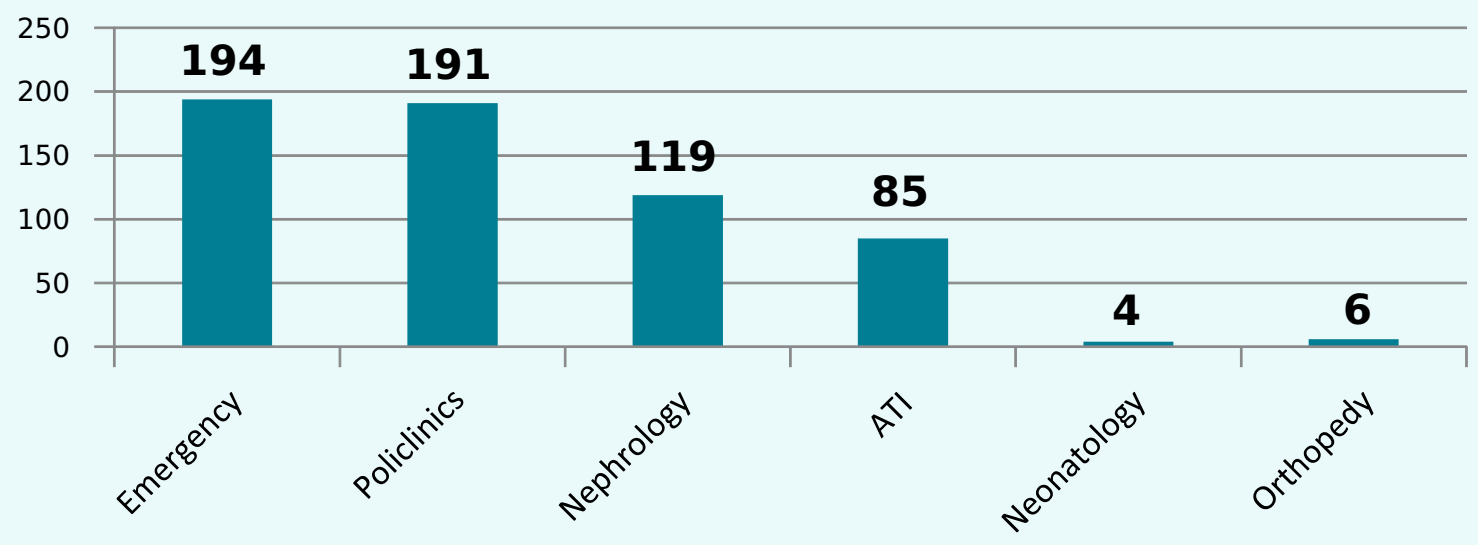

Figure4. Distribution depending on the medical section

cases, it is caused by the proliferation of $\mathrm{E}$. coli type bacteria, originating from the anal area. All obstacles that prevent bladder emptying increase the risk of cystitis. Cystitis is usually accompanied by urethritis. Urethritis is an infection of the urethra and is a common sexually transmitted disease in men, but it can rarely occur in women as well. Various infectious agents can cause urethritis, the most common of them being chlamydia and gonococcus. Pyelonephritis is the inflammation of the pelvis and kidney, resulting from a bacterial infection. It may be a complication of an untreated cystitis, which allows the proliferation of bacteria from bladder to kidneys. Acute pyelonephritis occurs in women, especially in pregnant women.
Pathogenic bacteria that produce UTI are Gram-negative species such as Escherichia coli, Klebsiella, Proteus, Enterobacter, Pseudomonas aeruginosa, Serratia spp., and Gram-positive organisms including the group of B streptococcus, Enterococcus spp. and Staphylococcus aureus ${ }^{(5)}$.

\section{Material and methods}

The purpose of this study is to evaluate the prevalence of ESBL, CPE multidrug-resistant bacteria in urinary tract infections in the County Emergency Clinical Hospitalof TârguMureş during 2017-2018.

The study is a retrospective one in which we analysed the observation sheets of 1630 
patients, hospitalized or comingon an outpatient basis for investigations between January 1, 2017 and December 31, 2018 in the County Emergency Clinical Hospital of Târgu-Mureş. The analysed data refer to laboratory analyses especially to pathological products of urine.

For the statistical analysisl used Chi-Square Tests and MS Excel.

\section{Results}

At the distribution of patients according to their gender in a batch of 1630 patients, there are 1215 women (74.5\%) and 415 men $(25.5 \%)$. Following an age distribution of the studied patients, we observed that the average age is 54 years.

I found 1119 patients (68.7\%) with spontaneously emitted urine through the middle jet, 200 patients (12.3\%) with urine collected through newly introduced catheter, 310 patients (19\%) by permanent catheter and 1 single patient $(0.1 \%)$ with urine collected through a stoma-catheter.

Following this distribution, we noticed that most samples of ESBL and CPE resistant enterobacteria. The most cases I found in Emergency Department, where a total of 194 (11.9\%) patients come from the total of the ones studied by us, being closely followed by the patients from the Policlinics- 191 (11.7\%) patients. Other sections where we see more resistant bacteria in a larger number are nephrology-119 patients (7.3\%), ATI (Anaesthesia and Intensive Therapy) -85 patients $(5.2 \%)$ and neurology-168 patients (10.3\%).

The fewest cases of resistant enterobacteria were seen in patients with CCV-3 patients $(0.2 \%)$, neonatology-4 patients $(0.2 \%)$, paediatric hematology 6 patients $(0.4 \%)$ and orthopaedics -6 patients $(0.4 \%)$.

\section{Discussions}

Regarding the gender of the patients included in the study, it can be observed that the urinary tract infections producing enterobacteria occur mainly in women as compared to men, as demonstrated in another study such as "Extended-spectrum beta-lactamase producing bacteria in a tertiary care hospital in Madrid: epidemiology, risk, factors and antimicrobial susceptibility patterns ${ }^{11(6)}$.

The way of collecting the urine product in our group of patients is mostly the middle jet through spontaneous emission. A not very small number of samples are collected through the catheter (newly inserted or permanent). The urinary tract infection attributed to the use of a urinary catheter is one of the most common infections acquired by patients in the healthcare units ${ }^{(7)}$.

Carbapenems are the preferred antimicrobials in the treatment of serious infections, used in the case of microorganisms producing ESBL. Following our analysis, we noticed that we have CPE producing strains. In a Texas study, it has been demonstrated that the use of carbapenems within 48 hours showed a tendency for early clinical success, but it was not a significant factor for the multivariate analysis. However, the use of carbapenems at any time after infections was associated with 28-day survival in univariate analysis ${ }^{(8)}$. Moreover, according to the World Health Organization, the report of 2014 shows that the epidemiology of CPE is not well studied in developing countries, and therefore the report insisted that the integrated surveillance program and the involvement of a very active investigation should be maximized in order to know the magnitude of the resistant strains. Even though carbapenem drugs are not officially presented in Ethiopia, as the report 


\section{INTERNAL}

\section{Original Papers}

has stated, the international travels, globalization and migration may have a contributing role in the spread of resistant strains from countries with potential risk ${ }^{(9)}$.

\section{Conclusions}

Following the performed study, we can conclude that most urinary tract infections occur mainly in women than in men. Also, the average age when these urinary tract infections occur is around 54 years of age.

Most multidrug-resistant bacteria occur in patients hospitalized for a longer period. The microorganisms most commonly involved in urinary tract infections are Escherichia coli and Klebsiella pneumoniae. We can say that most multidrug-resistant bacteria are due to ESBL and CPE mechanisms.

\section{References}

1. Bronzwaer S, Lonnroth A, Haigh R. The European Community strategy against antimicrobial resistance. Euro Surveill. 2004; 9: 30-34.

2. Zhanel GG, DeCorby M, Adam H, Mulvey MR, McCracken $M$, Lagacé-Wiens $P$ et al. Canadian Antimicrobial Resistance Alliance, Hoban DJ. Prevalence of antimicrobial resistant pathogens in Canadian hospitals: results of the Canadian Ward Surveillance Study (CANWARD 2008). Antimicrob. Agents. Chemother. 2010; 54(11): 4684-4693.

3. Hoban DJ, Nicolle LE, Hawser S, Bouchillon S, Badal R. Antimicrobial susceptibility of global inpatient urinary tract isolates of Escherichia coli: results from the Study for Monitoring Antimicrobial Resistance Trends (SMART) program: 2009-2010 Diagn Microbiol Infect Dis. 2011; 70(4): 507-511.

4. American Journal of Infection Control, Volume 47, Issue 4, April 2019, Pages 371-375

5. Zorc J, Kiddoo DA, Shaw KN. Diagnosis and Management of Pediatric Urinary Tract Infections Clinical microbiology reviews. 2005, 18(2): 417-422.

6. Kaye KS, Schmader KE, Sawyer R. Surgical site infection in the elderly population. Clin Infect Dis. 2004;39:1835_41.

7. Hryniewicz K, Szczypa K, Sulikowska A, Jankowski K,Betlejewska K, Hryniewicz W (2001) Antibiotic susceptibility of bacterial strains isolated from urinary tract infections in Poland. J Antimicrob Chemother 47:773-780

7. Magill SS, Edwards JR, Bamberg W, Beldaus ZG, Dumyati G, Kainer MA, Lynfield R, Maloney M, McAllisterHollod L, Nadle J, Ray SM, Thompson D, Wilson LE, Fridkin SK: Multistate point-prevalence survey of health careassociated infections. N Engl J Med 2014, 370:11981208.

8. Paterson DL, Bonomo RA. 2005. Extended-spectrumlactamases: aclinical update. Clin. Microbiol. Rev. 18:657-686.

9. World Health Organization. Antimicrobial resistance. Geneva: WHO; 2014 